\title{
Tax or Trade: Community Energy Taxation in the Context of Climate Neutrality
}

\author{
Assoc. Prof. Dr. Svetlana Gercheva \\ University of Economics - Varna, Varna, Bulgaria \\ svetlana.gercheva@ue-varna.bg
}

\begin{abstract}
The instant paper considers the ecological taxation and emissions trading scheme as alternative market instruments for achieving carbon neutrality in the EU by 2050. In particular, the paper evaluates the capacity of the current energy taxation framework to contribute to zero net emissions. The analysis shows that EU energy taxation is detached from energy efficiency and the increasing share of clean energy consumption, which are important milestones for achieving climate neutrality. Such misalignment between climate and energy goals increases the social price due for carbon neutrality by duplicating the cost for energy taxation and emissions trading within the same economic sector. In Bulgaria, highly vulnerable to duplication of climate neutrality cost are the households and business sector. The most energy intensive industries in this country manage to negotiate tax incentives with the government, since they are mobile and can relocate to any other jurisdiction.
\end{abstract}

Keywords: energy taxation, excise duty on electricity, climate neutrality, low emission economy, quasi tax, obligation to society fee

JEL Code: H23, Q48, Q58 DOI: https://doi.org/10.36997/IJUSV-ESS/2020.9.1.168

\section{Въведение}

ЕС традиционно си поставя амбициозни климатични цели. Поредното предизвикателство е зелената сделка, в основата на която е постигането на климатично неутрална икономика в Общността към 2050 г. Това означава към 2030 г. чувствително намаление на въглеродния отпечатьк спрямо равнището му през 1990 г. и нулеви нетни емисии към средата на века. Ключова роля за осъществяването на зелената сделка е отредена на чистата енергия.

Климатичните и енергийните амбиции не са безплатни за обществото. Обект на тази статия е адекватността на настоящото енергийно облагане в ЕС за постигане на климатична неутралност, а предметът - отражението му в посока нейното оскъпяване както в Общността, така и в България.

\section{1. Климатичната неутралност и пазарният инструментариум за постигането й}

Постигането на климатично неутрална икономика до голяма степен зависи от възможностите за пазарно ценообразуване на въглеродния отпечатък. В научната литература, посветена на декарбонизацията на икономиката, в качеството на пазарни инструменти се анализират данъците с екологична насоченост и търговията с разрешителни (квоти) на парникови емисии (Baumol, 1972; Pizer, 1998; Stern, 2006; Hahn, 2006; Sinn, 2008; Stiglitz, 2015).

В първия случай посредством ставката на облагане държавата определя цена на единица замърсяване. В резултат, икономическите субекти настройват количеството вредни субстанции според данъчната „цена“. Алтернатива на налога с екологична насоченост е тьрговията с разрешителни (квоти) за вредни емисии. В този случай държавата (нейна институция) определя количеството допустимо замърсяване/желано почистване ${ }^{1}$. Квотите се търгуват на аукциони, където се постига равновесна цена на единица замърсяваща субстанция. И при двата инструмента се очаква вредните емисии да намаляват, докато пределните разходи за почистване за всеки източник на замърсяване се изравнят със ставката на данъка или с пазарната цена при схемите на търговия. Ето как допълнителните разходи за

\footnotetext{
${ }^{1}$ Не е задължително това да бъде ефективното му равнище.
} 
почистване се уеднаквяват (сближават) по източници на (причинители) на замърсяване, което е условие за разходна ефективност.

Основоположник на научния спор за избор на подходящ ценови инструмент за почистване на вредна за околната среда субстанция е Weitzman (1974). По онова време технологиите не са напреднали толкова, че прецизно да измерят замърсяването от различни източници при производство, търговия, потребление и пр. Weitzman съпоставя данъка върху замърсяването и количественото ограничаване на последното по критерия загуба на благосъстояние.

Цитираният автор счита, че данъчният инструментариум причинява по-малка загуба на благосъстояние, ако са налице няколко условия. Пьрво, прирастьт на ползата от единица почистване е по-малък от прираста на разходите за единица от същата дейност. Второ, има затруднения при определяне на фактическите пределни разходи за почистване в сравнение с прогнозираните. Ако разминаването между тях се окаже значително (заради несигурността при прогнозирането на пределните разходи), данъкът ще причини по-малка загуба на благосъстояние, отколкото количественото ограничаване на климатичните промени. Трето, според Weitzman по-вероятни са грешки при целеполагане на почистването на вредните емисии. Тогава дори и при перфектно прогнозиране на пределните разходи, погрешното определяне лимита на замърсяването ще причини значителна загуба на благосъстояние. Почти 40 години по-късно Stiglitz споделя разочарованието си от слабия напредък на науката, която не може категорично да определи колко точно да се намали количеството емисии, за да не се допусне затопляне на климата с повече $2^{\circ} \mathrm{C}(2015, \mathrm{p} .33)$.

В по-съвременно изследване Weitzman добавя нов аргумент в подкрепа на акциз (данък) вместо количествен лимит на въглеродни емисии (2015, р.39). Според него националните държави са в състояние да договорят по-висок въглероден данък в глобален аспект. Последното обаче е оспоримо, предвид директивата на ЕС за енергийно облагане. Там се вижда, че националните държави по-скоро се договорят за минимално допустимите размери на данъците, но не и за увеличението им. Crampton et al. (2015) също се застъпват за глобален въглероден данък. Авторите се позовават на волатилната цена на $\mathrm{tCO}_{2 \mathrm{e}}$ в рамките на схемите за търговия с разрешителни за вредни емисии. Според тях акцизното облагане на единица замърсяваща субстанция преодолява ежедневните, сезонните или конюнктурни колебания на пазарната цена на разрешителните. Правителството обикновено фиксира и съумява да поддържа постоянна данъчната ставка на единица въглероден отпечатък в рамките поне на фискалната година.

В миналото се наблюдава добре изразена поляризация на мнения относно избора на ценови инструмент на замърсяването. Първата група автори категорично поддържат данъците с екологична насоченост (Mankiv, 2006; Nordhouse, 2007). Втората група търговията с разрешителни за парникови емисии (Ellerman et al.,2003; Keohane, 2009). Напоследък обаче данъкът върху въглеродното замърсяване и схемите за търговия на $\mathrm{CO}_{2}$ се разглеждат като еквивалетни мерки срещу изменението на климата (Stiglitz, 2015, p.33). Същото мнение споделя и Stavins, като според него изборът между двата пазарни инструмента “...често се оказва [просто] избор на дизайн на отделни елементи в рамките на на един и същ политически континуум““(2019, p.3).

Еквивалентността на въглеродни данъци и схеми за търговия с квоти се аргументира от много автори в редица направления, систематизирани от Stavins. Това са потенциалът на двата пазарни инструмента да намаляват вредните емисии и да акумулират държавни приходи, разходите за почистване, административното бреме на регулираните субекти, преразпределителните аспекти и отражението върху конкурентноспособността на бизнеса (Stavins, 2019, pp.5-8).

Статистическите сравнения сочат, че е налице приблизително равновесие от гл.т. „разделение на труда“ между акцизите и системите за търговия като ценови инструменти за 
климатично неутрална икономика. Екологично насочените данъци се прилагат към 45,54\% от вредните емисии, а схемите за търговия - към 48,10\% от тях (Haites, 2018, p. 958). В този дух Stiglitz, а преди него и други изследователи, формулират хибриден подход към ценовото ограничаване на вредните емисии (Cooper, 2008, p. 27; Stiglitz, 2015, p. 33). Той се основава на гъвкавост и свобода на избор според националните предпочитания между данъци и търговия с разрешителни, защото те се интерпретират като тъждествени при ограничаване на вредните емисии

Обзорьт на обширната научна литература, посветена на пазарните инструменти за климатична неутралност, се фокусира върху тяхната еквивалентност. Те се оценяват като съвършени или поне близки заместители за постигане редукция на въглеродния отпечатък. Акцентира се на възможността за свързване в рамките на „разделението и специализацията на труда“" между тези инструменти. Това означава, че данъците с екологична насоченост ценообразуват въглеродния отпечатък в едни отрасли (икономически дейности), докато схемата за търговия „покрива“ други. Евентуалното им дублиране в рамките на даден отрасъл (икономическа дейност) е неприемливо. То ще оскъпи значително почистването и ще отложи във времето климатичната неутралност.

\section{2. Енергийното облагане в ЕС: „дълголетие“ в нова реалност?}

През 2003 г. в ЕС е приета директива за енергийното облагане, с която Общността си поставя множество разнопосочни цели: климатични съгласно Протокола от Киото, енергийна ефективност, конкурентноспособност (при предстоящо разширяване с по-слабо развити икономики), изграждане на единен вътрешен пазар на енергопродукти (European Commission, 2019, p.8). Всяка от целите поотделно е обществено значима, но големият им брой е в разрез с „правилото“ на Тинберген: една цел - един инструмент (Tinbergen, 1952). Ето защо Парламентът и Съветьт на ЕС приемат и директива за създаване на схема за търговия с разрешителни за парникови емисии (Директива 87/2003/ЕС). В разгара на глобалната криза - през 2009 г. - са одобрени изисквания за екодизайн към продукти, свързани с енергопотребление (известни впоследствие като директива за енергийна ефективност) и законодателен акт за възобновяемата енергия (директива 2009/28/ЕС).

Направената дотук ретроспекция не е самоцелна. Тя очертава амбициозните цели на Общността за опазване на околната среда и климата. Освен това се вижда, че ЕС полага последователни усилия въпреки финансовата и дългова криза от 2008-09 г. Сега историята като че ли се повтаря. При безпрецедентна здравна и икономическа криза Общността не се отказва да търси възможни политически решения едновременно за възстановяване на икономиките от COVID-19 и провеждане на зелена сделка. Целта на последната е нискоемисионна, а към средата на века и на климатично неутрална икономика в ЕС.

От приемането си през 2003 г. досега директивата за енергийно облагане на Общността се радва на забележително дълголетие. Тя не е променяна, независимо че е „пресечна точка“ на динамично развиващи се единен вътрешен пазар, енергетика, транспорт и мерки за опазване на климата. Що се отнася до единния вътрешен пазар, въвеждането на минимални акцизни ставки на невъзобновяемите енергоносители може да се оцени като успех. Първо, долните граници на облагане възпрепятстват „съревнование към дъното“ между СЧ. Всяка от тях желае да акумулира повече енергийни данъци при по-ниски размери на облагане. Второ, стига последните да не са под минимума, разписан в директивата, всяка СЧ може да определя онази акцизна ставка, за която се постигат нейните приоритети фискални, икономически, екологични, социални и пр.

Ако през 2003 г. вътрешният пазар „води“ дневния ред на ЕС, то нискоемисионната и климатично неутрална енергетика и икономика все още са футурология. Ето защо настоящата добавена стойност на директивата за енергийно облагане е спорна, що се отнася до амбициозните климатични цели на ЕС. През последните години в контекста на мобилността потреблението се променя от нефтопродукти към електрическа енергия. В 
директива 2003/96/ЕС подобна тенденция няма как да се предвиди. Там акцизът върху електроенергията се диференцира според потребителя - домакинство (мин. $€ 1,00 / \mathrm{MWh})$ или бизнес (мин. $€ 0,50 / \mathrm{MWh}$ ). При въглищата, кокса и природния газ ставките сьщо са по-ниски за бизнеса и по-високи за домакинствата (Directive 2003/96/EC, Annex I, table C).

От 2003 г. досега невъзобновяемите горива се облагат според масата или обема (в $€ / 1000$ кг. или $€ / 1000$ литра). Така определени, минималните ставки на акцизите са произволни. От гл.т. енергийно съдържание или въглероден отпечатък те „изпращат“ деформиран сигнал относно цената/разходите на различните енергоносители. Ако минималните ставки, разписани в директива 2003/96/EC, се преизчислят според енергийното съдържание и се добавят $\mathrm{CO}_{2}$ емисиите на последното, класацията би изглеждала така:

Таблица 1. Избрани енергоносители според въглероден отпечатък и цена на енергийно съдържание

\begin{tabular}{|l|r|rr|}
\hline \multicolumn{1}{|c|}{ Енергоносител } & \multicolumn{1}{|c|}{$\begin{array}{c}\text { Цена на енергийно } \\
\text { съдържание (€/GJ) }\end{array}$} & \multicolumn{2}{c|}{$\begin{array}{c}\text { Въглероден отпечатък } \\
\text { (кг. СО2/GJ) }\end{array}$} \\
\hline Въглища & 0,15 & 228 \\
\hline Електроенергия & 0,28 & 56 \\
\hline Природен газ & 2,60 & 63 \\
\hline LPG & 4,71 & & 74 \\
\hline Газьол & 8,55 & & \\
\hline Керосин & 8,71 & n.a \\
\hline Бензин & 10,50 & n.a & \\
\hline
\end{tabular}

От табл.1 (средна колона) става ясно, че от гл.т. разходна ефективност икономическите субекти ще предпочетат, при равни други условия, въглища и електроенергия, респ. газьол и керосин, доколкото отношението „данъчна „цена“ - енергиен капацитет“ е най-изгодно. Подобен избор може да повиши енергийната ефективност, но със сигурност няма да осигури нискоемисионна и климатично неутрална икономика нито към 2030 г., нито към 2050 г. Причината е, че разходно ефективните горива откъм енергийно съдържание генерират при употреба значителни въглеродни емисии (последна колона). При настоящия енергиен микс електрическата енергия генерира 228 кг., а въглищата - 101 кг. въглероден диоксид за едно и също енергийно съдържание (1 гига джаул). Следователно акцизите във вида от 2003 г. „изпращат“ деформирани ценови сигнали, които не са обвързани с щетите на вредните емисии и се нуждаят от осъвременяване. Предвид амбициозните климатични цели, енергийното облагане в Общността трябва да се съгласува с останалите инструменти за нискоемисионна и климатично неутрална енергетика европейската схема за търговия с емисии и увеличаване дела на възобновяемата енергия в крайното потребление. В противен случай разходите за опазване на климата ще са неравномерно разпределени по икономически дейности: някои ще бъдат многократно „притиснати“, докато други - „ще минат метър“.

В името на обективността следва да се уточни, че през 2011 г. европейската комисия предлага промяна в дизайна на данъчните ставки за невъзобновяемите енергоносители и електрическата енергия (EC, $\operatorname{COM}(2011) 169$ final). Цитираният проект за ревизия на директива 2003/96/ЕС обаче е неуспешен и е официално оттеглен през 2015 г. Независимо от това, интерес представлява предложеният нов начин за определяне на акцизните ставки за невъзобновяемите източници на енергия. В ревизията от 2011 г. въглеродното замърсяване на последните е оценено на $€ 20 /$ тон $\mathrm{CO}_{2}$, докато енергийната компонента варира и е много близка до изчисленията, онагледени на фиг.2 (COM(2011) 169 final, annex I).

В крайна сметка според проекта от 2011 г. акцизната ставка на невъзобновяемите горива е сума от въглеродна и енергийна компонента. Макар че унифицираната цена от 
$€ 20 /$ тон $\mathrm{CO}_{2}$ не е подходяща за енергоизточници с твърде различен въглероден отпечатък, предложението на Комисията от 2011 г. може да послужи като ориентир какъв трябва да е дизайнъm на акцизите в случай на ревизия. За тази препоръка могат да се приведат следните аргументи. Първо, ако ставката на акциза е сума на енергийна и екологична компонента, се залага по-добра „настройка“ между целите за редуциране на вредните емисии и за енергийна ефективност. Второ, енергийното облагане се адаптира в контекста на нискоемисионна (към 2030 г.), а впоследствие и климатично неутрална икономика (към 2050 г.)

Енергийното облагане на ЕС е обект на критики и поради вградените в организацията му щедри данъчни стимули. Недоволстват както СЧ в опит да защитят фискалните си интереси, така и стейкхолдери заради деформираната неутралност на облагане (European Commission, 2019). Данъчните облекчения, разписани в директивата от 2003 г., се предоставят под формата на освобождаване, възстановяване и прилагане на редуцирани ставки. От енергийни акцизи се освобождават цели отрасли (подотрасли): въздухоплаване, корабоплаване, енергопродукти с двойно предназначение, респ. влагани за производство на електрическа енергия. Възстановяване се прилага за енергоинтензивни индустрии, оператори на железопьтна инфраструктура, лицензирани ж.п. превозвачи, както и в електролитни, металургични и минералогични производствени процеси. Редущирани ставки ce предвиждат според предназначението на енергоизточниците - за отопление, в индустрията, селското стопанство и домакинства (Gercheva, 2013, p.137).

Освен фискални и проблеми с неутралността на облагане, щедрите „жестове“ на наднационалните институции нарушават принципа „замърсителят плащза“. Отрасли и икономически дейности, бенефициенти на систематизираните по-напред данъчни стимули, променят климата, без да плащат пропорционално на нанесената щета. В същото време останалите плащат многократно - с акцизи, такси и с разходи за покупка на квоти за замърсяване. На фиг.1 се вижда разпределенито на въглеродното ценообразуване по отрасли и кои от тях са най-тежко засегнати (OECD, 2016).

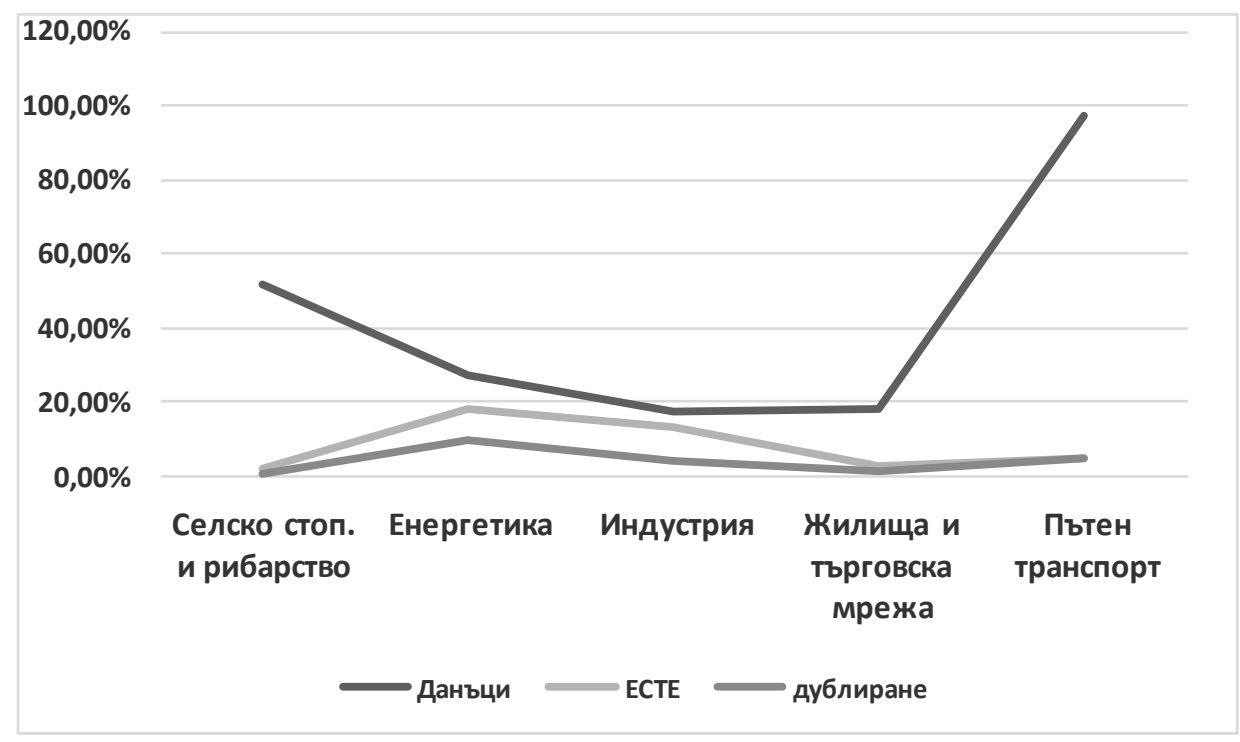

Фигура 1. Разпределение на въглеродни емисии по инструмент на ценообразуване и по отрасли

Фиг.1 се базира на данни от ОИСР, където членуват 41 юрисдикции, прилагащи „разделно“ както данъци, така и схеми за търговия с вредни емисии. Представеното на фиг.1 „разделение на труда“ във въглеродното ценообразуване сочи “специализацията“ на данъчния инструментариум. С него се остойностяват вредни емисии предимно в пьтния транспорт, селското стопанство, рибарството и електроенергетиката. За сравнение, схемата 
за търговия „продава“ най-много квоти за замърсяване на индустрията и енергетиката. На фиг.1 се вижда и дублирането на данъчно облагане и схеми за търговия в един и същ отрасъл. От него най-потьрпевши са електроенергетиката, индустрията и пътният транспорт.

На практика в тези отрасли данъците и разходите за покупка на квоти за вредни емисии от алтернативни ценови инструменти се превръщат в дублирани. Последица от тази трансформация е, че в енергетиката, индустрията и пътния транспорт несъразмерно се увеличават разходите за опазване на климата. Последното противоречи на теоретичните аргументи и препорьки, систематизирани в началото на публикацията.

Ето защо при бъдеща ревизия на енергийното облагане в ЕС е редно критично да се преразгледат данъчните облекчения. Защо? Първо, пропуснатите заради тях данъци обикновено се събират там, където директивата не предвижда освобождаване, възстановяване и/или редуцирани (нулеви) ставки. Второ, то е следствие на първото - в рамките на данъчния инструментариум може да се причини натрупване на акцизи, респ. такси и отчисления с квази-данъчен характер. Последното допълнително оскъпява въглеродното замърсяване. Трето, в бъдеще не е оправдано наслагването в рамките на един и същ отрасъл на данъци и разходи по повод търговията с емисии.

\section{3. Чистата енергия в България - в лабиринта от данъци и такси}

България транспонира директивата от 2003 г. за енергийното облагане чрез закона за акцизите и данъчните складове още преди пълноправното си членство в ЕС. Практиката по прилагането на закона в България възпроизвежда основни слабости на директивата - акцизни ставки, съобразени единствено с минималните изискуеми от EC, без оглед на енергийна ефективност.

Предвид ограничения обхват и проблематиката на настоящата публикация, се фокусираме по-конкретно върху индиферентността на енергийното облагане у нас към възобновяемата енергия и необходимостта финансовата подкрепа за нея да се регламентира фрагментирано в съпътстваща и непрекъснато изменяна нормативна уредба.

По примера на ЕС и България се ангажира със стимулиране производството на чиста енергия от вода, вятър, слънце и биомаса. Разпоредбите на ЗАДС обаче показват, че България търси баланс единствено между съблюдаването на вторичното законодателство на ЕС и минималното обременяване на електроенергията за бизнеса и домакинствата с акциз. Без значение дали токът е произведен от възобновяеми или невъзобновяеми източници, домакинствата у нас са освободени, а бизнесът (небитовите абонати) плащат 2 лв./MWh (ZADS, Art.34).

Финансовата подкрепа за производството на чиста енергия у нас се реализира посредством включената в цената на електроенергията „зелена“ добавка. Пьрвоначално тя е в размер на 2,12 лв./MWh (ДКЕВР², 2009). От 2010 г. се прилага и „кафява“ добавка от 2,19 лв./MWh по повод високоефективното комбинирано производство на електро- и топлоенергия (т.нар. ко-генерация) (ДКЕВР, 2010). „Цветните“ добавки увеличават цената на тока за краен потребител. Така се компенсират по-високите разходи на Националната електрическа компания (НЕК) $)^{3}$ за изкупуване на енергията от възобновяеми източници (ВИ) и от ко-генерация. От средата на 2014 г. „цветните“ добавки вече се включват в такса на $\mathrm{MWh}$, известна като „Задължения към обществото“ (ДКЕВР, 2014). Нейният размер се определя и променя периодично от КЕВР 4 . Освен „цветните“ добавки в общия размер на такса „Задължения към обществото“ (такса "ЗО“) регулаторьт изчислява и включва суми за компенсиране на НЕК по договори за дългосрочно изкупуване на електроенергия от ТЕЦ „Ей И Ес Марица - Изток 1““ ЕООД и „Контур Глобал Марица Изток 3“ АД (Zakon za

\footnotetext{
2 Държавна комисия за енергийно и водно регулиране, преименувана по-късно на комисия за енергийно и водно регулиране (КЕВР).

${ }^{3}$ В качеството му на обществен доставчик на електроенергия у нас.

${ }^{4}$ Обикновено важи за периода 1.07. текущата година - 30.06 на следващата.
} 
energetikata, Art.35).

Такса „3О“ се изчислява за цялото количество потребена електроенергия в страната и се заплаща както от битови, така и от небитови (стопански) клиенти (Zakon za energetikata, Art.35a). Доколкото понастоящем България е единствената страна в ЕС, където едновременно работят свободен и регулиран пазар на електроенергия, бизнесът „вижда“ таксата „3О“ като добавка към договорената цена на тока на свободния пазар. За домакинствата, които все още са на регулирания пазар, таксата е „невидима“- тя е неразделна част от цената на активната енергия 5 .

Какво е общото между такса „3О“ и акциза върху електроенергията, определен в ЗАДС? Независимо че в наименованието на таксата липсва терминът „данък“, тя обективно е квази данък (с екологична насоченост). Защо? Първо, компонентът за зелена енергия и за когенерация се заплаща от всички клиенти (битови и небитови), както и от електропреносния и енергоразпределителните оператори у нас. Наистина задължението за такса „3О“ не е определено в данъчното законодателство. Но таксата съвсем не е произволна - разписана е в закона за енергетиката у нас. Последното обстоятелство не омаловажава данъчната същност на такса „3О“. Второ, съдържащите се в нея добавки за зелена енергия и когенерация също имат характер на специфичен акциз - държавният регулатор ги фиксира в лева на MWh потребена електроенергия. Трето, и акцизите, и такса „3О“ могат да се променят във времето. Единствената разлика е, че решението за данъците се взема от Народното събрание, докато за таксата - от КЕВР. Четвърто, както акцизите, така и такса „ЗО“ с нейните „цветни“ компоненти, се включват в крайната цена на електрическата енергия. Така добавките се заплащат от битови и небитови абонати без оглед тяхното желание или информираност.

След като аргументирахме родството между акциза и такса „3О“ е подходящо да анализираме нейния размер и структура. Тези параметри са показани на фигура 2. В структурата на таксата „цветните“ добавки са разграничени от компенсациите за НЕК при дългосрочно изкупуване на електроенергията на двата ТЕЦ (на диаграмата компенсациите фигурират като други). Пьрвоначално такса „3О“ е между 35-40 лв./МВтч, а впоследствие спада наполовина (вж. фиг.2).

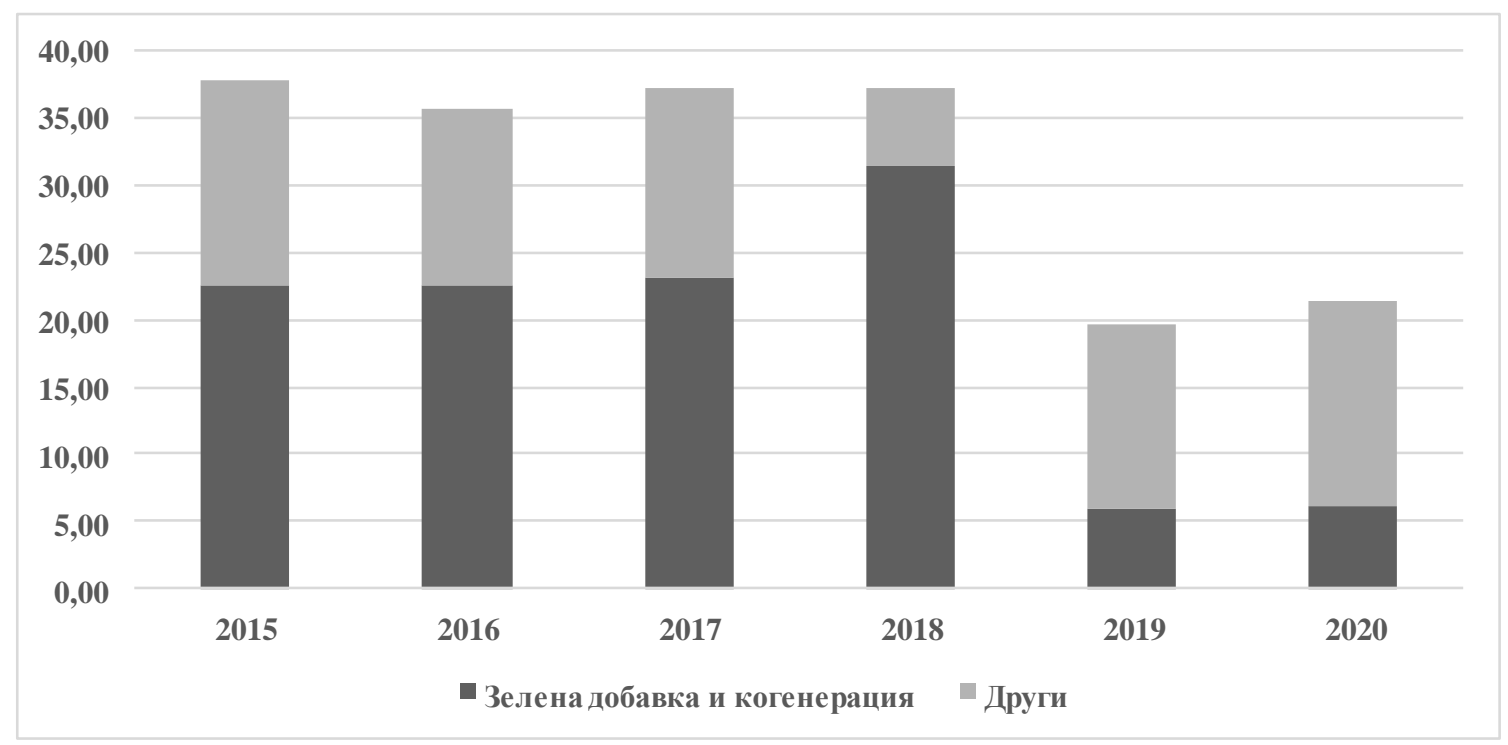

Фигура 2. Цена (такса) „Задължения към обществото“ (лв./MWh) Източник: Решения на КЕВР

\footnotetext{
5 От 01.10.2020 г. на свободния пазар са и МСП, които трябва самостоятелно да избират доставчик на електроенергия. Домакинствата не са задължени да купуват от регулирания пазар. Въпреки това незначителна част от тях са на свободния пазар на електрическа енергия.
} 
През първите три години от разглеждания период компонентът за стимулиране на високоефективната ко-генерация не е прибавен към добавката за енергия от ВИ 6 . От 2018 г. насам добавката за зелена енергия и за ко-генерация са показани на фигурата като сума. Ето защо може да се счита, че през 2015 г. - 2017 г. „цветните“ добавки са относително постоянен „пласт“ на таксата „3О“. През 2019 и 2020 г. цената „3О“ намалява, вследствие на по-ниските „цветни“ добавки (вж. фиг.2). Как става това? Все повече производители у нас продават електроенергия на Българската независима енергийна борса (БНЕБ). Постигнатата там средна цена $/ \mathrm{MWh}^{7}$ обикновено е по-висока от среднопретеглената за битови потребители на регулирания пазар. Поради по-високата цена на свободния спрямо регулирания пазар, на производителите на чиста и високоефективна енергия вече не се дължат толкова много компенсации по линия на такса „ЗО“. Затова нейният размер намалява през последните две години на разглеждания период.

От направения анализ на размера и структурата на такса „3О“ става ясно, че сметката за ток и на домакинства, и на небитови абонати у нас се оскъпява ежегодно през периода 2015-20 г. с между BGN20 и BGN40/MWh. потребена електроенергия. Това оскъпяване представлява своеобразен (квази) акциз, периодично определян (изменян) от КЕВР. В същото време ЗАДС освобождава от акциз тока на домакинствата и облага бизнеса с 2 лв./MWh. Домакинствата е редно да са по-малко обременени с данъци, предвид по-ниската си платежоспособност в сравнение с бизнеса. И действително в сметката си за ток те плащат само такса „3О“. Тя обаче се оказва 10-20 пьти по-висока от минималния акциз от $€ 1 / \mathrm{MWh}$ електроенергия, предвиден от директивата за енергийно облагане от 2003 г.

Наред с таксата „3О“ българските домакинства могат да бъдат обременени и с още плащания за опазване на климата, ако бизнесът им прехвърли в цената на продукцията си платените от него акциз и такса „3О“. Подобна прехвърляемост на данъка (квази-данъка) е реалност при ценово нискоеластично или нееластично потребление. А ако по пътя на стойностната верига в цената за домакинствата вече са включени и разходите на някои индустрии за покупка на квоти за вредни емисии? Тогава на фона на ниската си платежоспособност домакинствата у нас ще се окажат претоварени по повод беземисионна и високоефективна енергетика. Чрез цените на стоките/услугите, които потребяват, домакинствата плащат акциз, квази-данък (такса) и покриват разходи на индустриите за покупка на въглеродни квоти.

Струпване на такива плащания може да се установи и при бизнеса у нас. С оглед нискоемисионна енергетика и запазване на климата от фирмите се събират „цветните“ добавки на такса „3О“. Те са в същия размер като при домакинствата. Наред с това бизнесът дължи и акииз в размер на $€ 1 / M W h$ консумирана енергия. Разходите на бизнеса за акциз и такса „3О“ се представят на фиг. 3

„Цветните“ добавки доминират разходите на бизнеса за чиста енергия и нискоемисионна икономика. Поради липса на достатъчно информация плащанията на стопанските абонати (определени индустрии) за въглеродни квоти не са показани на фиг.3.

За да не се получи превратна представа за бремето на бизнеса по повод климатично неутрална икономика, трябва да се прецизира, че енергийното облагане у нас е относително диференцирано и държи сметка за спецификата на работа на различните производства. $3 a$ енергоинтензивните индустрии директивата на ЕС предвижда опщия за възстановяване на акциз. В България се възстановява акцизът за електроенергия, чиято стойност надвишава $50 \%$ от стойността на крайния продукт (ZADS, Art. 24zh, t.2). Става въпрос за икономически дейности като добив на въглища, черни и цветни метали, производство на тухли, керамика, стъкло, на хартия и картон, на химически торове и др. Наред с възстановяването на акциза за потребената електроенергия крупните индустриални консуматори имат право и на

\footnotetext{
${ }^{6}$ Няма подробна разбивка в решенията на КЕВР относно „цветните“ добавки на такса „3О“.
}

${ }^{7}$ Става дума за цена на базов товар - тя не съдържа все още такси, добавки, данъци и пр. 
отстъпка от „зелената“ добавка на такса „Задължения към обществото“.

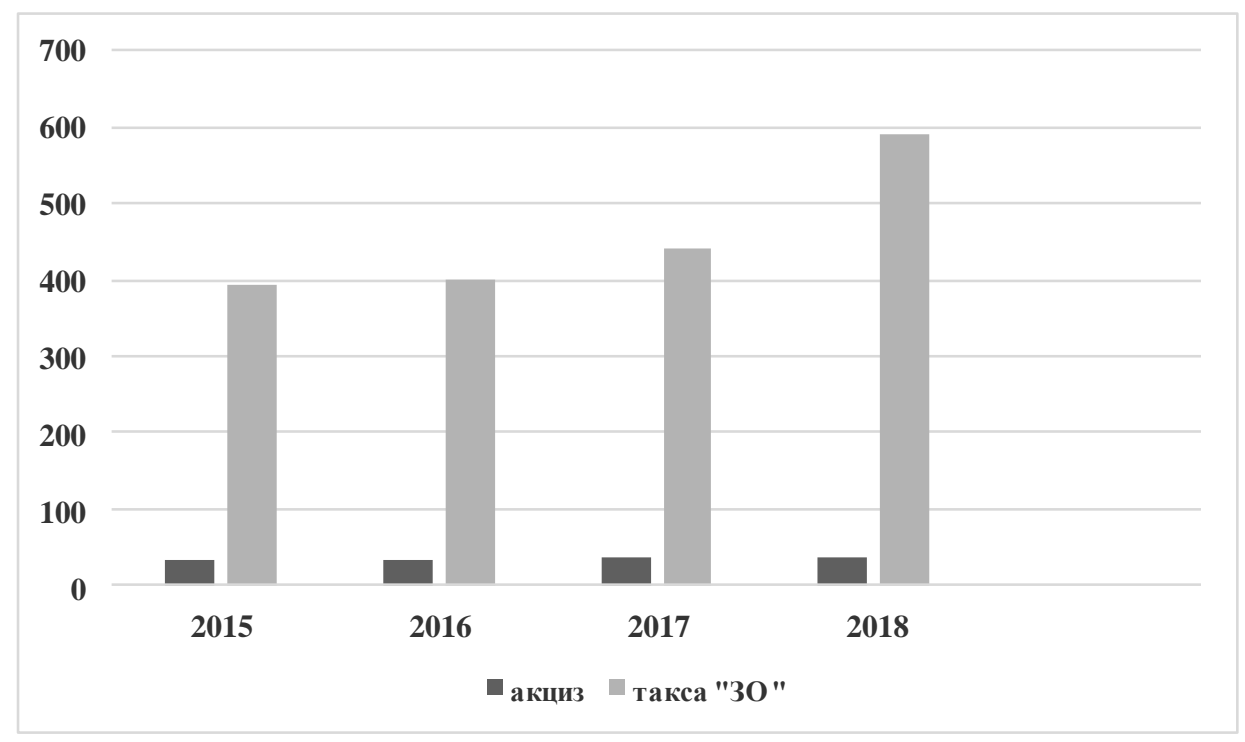

Фигура 3. Разходи на бизнеса за акциз и „цветни“ добавки, млн. лева

Източник: Собствени изчисления по данни на European Commission (акциз) и КЕВР (такса „3О“)

До 2016 г. отстьпката зависи от консумираното количество електроенергия в индустриалното предприятие. Това решение е контрапродуктивно от гл.т. редуциране на въглеродния отпечатьк. Пьрво, колкото по-висока е консумацията на ток, толкова по-голяма e отстьпката от таксата. Следователно толкова по-ниска е цената/MWh потребена електроенергия (големите индустриални предприятия у нас договарят цената на тока на свободния пазар, а такса „Задължения към обществото“ е добавка към нея). Второ, отстьпката на практика е данъчен стимул да се свръхпотребява ток от и без друго енергоинтензивни индустрии у нас. Трето, в енергийния микс на България доминират въглищата и ядрената енергия. Следователно отстьпката от „зелената“ добавка не е стъпка към ниско емисионна енергетика и индустрия. Тя допринася за възпроизвеждане на замърсяващия енергиен микс у нас. Ето защо отстьпката от „зелената“ добавка за енергоинтензивни индустрии вече се диференцира според електроинтензивността ${ }^{8}$ на предприятията (Наредба № Е-РД-04-06, чл. 4 (1)).

Възстановяването на акици и предоставянето на отстъпка от ,зелената“ добавка са данъчни стимули, специално таргетирани към енергоинтензивните индустрии у нас. Тук отстьпката от ,зелената“ добавка е обоснована, за да не се натрупват в цената на тяхната продукция разходи и за данъчно облагане, и за търговия с квоти. Схемата на ЕС за търговия „покрива“ вредните емисии на енергоинтензивните индустрии още от 2005 г. насам (Naredba, Prilojenie №1 kum Art.3 (2), t.1). Голям брой електроинтензивни производства в България купуват въглеродни квоти по пазарни цени на първичните аукциони на Европейската енергийна борса в Лайпциг. „Щедростта“ на държавата в случая „дава гльтка въздух“ на конкурентноспособността на тези индустрии, като същевременно ревизира данъчните облекчения за по-адекватна обвръзка с нискоемисионната икономика.

Комплицираната организация на такса „Задължения към обществото“ с включените в нея добавки и прилаганите отстъпки, плащането и възстановяването на акцизи илюстрират противоречивото имплементиране на директивата за енергийно облагане у нас. Липсата на

\footnotetext{
${ }^{8}$ Тя се определя въз основа на дела на разходите за електроенергия към БДС на компанията.
} 
съгласуваност между амбициозните климатични, енергийни цели и запазването на конкурентноспособността са причина секторьт на домакинствата и част от бизнеса да са претоварени с разходи по повод климатична неутралност. В същото време на примера на електроинтензивната индустрия се демонстрира колко важна е мобилността на бизнеса за дизайна на данъчните облекчения. Опасявайки се, че мобилните производства могат да напуснат юрисдикцията й, държавата е готова да ги разтовари от прекомерни разходи за климатично неутрална икономика.

\section{Заключение}

Важно макар и неписано правило е да се съблюдава „разделението и специализацията на труда“" на данъците върху въглеродния отпечатьк и на схемата за търговия с квоти за вредни емисии. В свое становище по повод на евентуалната ревизия на директивата за енергийно облагане част от стейкхолдерите ясно разграничават двата пазарни инструмента като алтернативи, а не дублиращи се. „Или облагай, или търгувай, но не и двете заедно“ е категоричното им мнение.

\section{References}

1. Baumol, W. (1972) On Taxation and Control of the Externalities. The American Economic Review 62 (3).

2. Cooper, R. (2008) The Case for Charges on Greenhouse Gas Emissions. Harvard Project on 2. International Climate Agrements. Discussion paper 08-10.

3. COUNCIL DIRECTIVE 2003/96/EC of 27 October 2003 restructuring the Community framework for the taxation of energy products and electricity. Official Journal of the EU. 31.10.2003 L283/51-70.

4. Cramton, P., Ockenfels, A. and Stoft, S. (2015) An International Carbon-Price Commitment Promotes Co-operation, Economics of Energy and Environmental Policy. 4 (2), pp.51-64.

5. DKEVR (2009) Reshenie № C- 23 ot 25.06.2009.

6. DKEVR (2014) Reshenie № C-12 ot 30.06.2014.

7. EURACOAL (2020) Response to public consultation on the proposed revision of the Energy Taxation Directive 2003/96/EC restructuring the Community Framework for taxation of energy products and electricity. Available from: https:euracoal.eu [Accessed 03/10/2020].

8. European Commission (2011) Proposal for a Council Directive amending Diretive 2003/96/EC restructuring the Community framework for the taxation of energy products and electricity. $\operatorname{COM}(2011) 169$ final. Brussels. 13.04.2011.

9. European Commission (2019) EVALUATION of the Council Directive 2003/96/EC of 27 October 2003 restructuring the Community framework for the taxation of energy products and electricity. SWD(2019) 332 final. Brussels.11.09.2019.

10. Gercheva, S. (2013) Danuci s kauza. Ekodanucite srestu zamursiavaneto na okolnata sreda. Varna : STENO Publ. House.

11. Haites, E. (2018) Carbon taxes and green gas emissions trading systems: what have we learned? Climate Policy. 18 (8), pp.955-966.

12. KEVR (2015) Reshenie № C -27 ot 31.07.2015.

KEVR (2015) Reshenie № C - 35 ot 01.11.2015.

KEVR (2016) Reshenie № C - 19 ot 30.06.2016.

KEVR (2017) Reshenie № C - 7 ot 07.04.2017.

KEVR (2018) Reshenie № C - 11 ot 01.07.2018.

KEVR (2019) Reshenie № C - 19 ot 01.07.2019.

KEVR (2020) Reshenie № C - 29 ot 01.07.2020.

13. ME (2016) Naredba № E-RD-04-06 za namaliavane a tejestta, svurzana s razhodite za energia ot vuzobnoviaemi iztochnici, obn. State Gazette, br. 77 ot 4 oktomvri 2016 g. 
14. OECD (2016) Effective carbon rates: Pricing $\mathrm{CO}_{2}$ through taxes and emissions trading systems. Paris: OECD Publishing. Available from: https://www.oecd-ilibrary.org/taxation/effectivecarbon-rates_9789264260115-en [Accessed 07/10/2020].

15. Nordhouse, W.D.(2007) To Tax or Not to Tax: Alternative Approaches to Slowing Global Warming. Review of Environmental Economics. 1 (1). Winter 2007.

16. Pizer, W. (1998) Prices vs. Quantities Revisited: The Case of Climate Change. Resources for the future. Discussion paper 98 (02).

17. Sinn, H.-W. (2008) Das gruene Pardoxon: Warum man das Angebot bei der Klimapolitik nicht vergessen darf? Available from: http://www.ifo.de [Accessed 17/10/2020].

18. Stavins, R.N. (2019) Carbon Taxes vs. Cap and Trade: Theory and Practice. Discussion paper ES 19-9. Cambridge Mass.: Harvard Project on Climate Agreements. November 2019.

19. Stiglitz, J. (2015) Overcoming the Copenhagen Failure with More Flexible Commitments. Economics of Energy and Environmental Policy. 4 (2), pp. 29-36.

20. Tinbergen, J. (1952) On the theory of economic policy. North Holland Publishing Co.

21. Weitzman, M. (1974) Prices vs.Quantities. Review of Economic Studies, 41 (4), pp. 477-491.

22. Weitzman, M. (2015) Internalising the Climate Externality: Can a Uniform Price Commitment Help? Economics of Energy and Environmental Policy. 4 (2), pp.37-50.

23. Zakon za akcizite i danuchnite skladove, obn. Durjaven vestnik, br.91 ot 15 noemvri 2005, izm. Durjaven vestnik, br.84 ot 29 septemvri 2020.

24. Zakon za energetikata, Obn. Durjaven vestnik. br.107 ot 9 dekemvri 2003 g. Izm. i dop. Durjaven vestnik, br.57 ot 26 Juni 2020. 